\title{
EL PROYECTO CON AGENTES NATIVOS DE LA MISIÓN JAMAICANA EN FERNANDO PÓO: SU HERENCIA COLONIAL ${ }^{270}$.
}

\author{
Susana CASTILlo-RodríGuEz ${ }^{271}$ \\ Saint Anselm College (EE.UU.)
}

Resumen: La obra de teatro de Philip. J. Fisher The Island Heritage. Episodes from the Missionary History of Fernando Poo, West Africa. A Play for Young People (1926) ha permanecido incógnita en los estudios sobre Guinea Ecuatorial. Su importancia reside, según argumentamos en este artículo, no solo en este hecho sino en lo que nos revela sobre el establecimiento de la Misión de la Sociedad Baptista Jamaicana en Fernando Póo entre 1842 y 1845 . Retomando los análisis de Bela Vassady (1979) y Dekar (2001), en este artículo se discutirá el papel de los "agentes nativos" jamaicanos en el proyecto misionero baptista y sus consecuencias para la expansión colonial británica al interior del continente africano.

Palabras Clave: misión baptista, Fernando Póo, agentes nativos.

Авstract: Philip. J. Fisher's play The Island Heritage. Episodes from the Missionary History of Fernando Poo, West Africa. A Play for Young People (1926) has

270 Este trabajo se enmarca dentro del proyecto HAR2012-34599, Lo que sabemos, ignoramos, inventamos y deformamos acerca del pasado y el presente de Guinea Ecuatorial. Revisión critica multidisciplinar y nuevas vías de investigación. Mi agradecimiento a los editores de este número especial sobre Guinea Ecuatorial en la revista ENDOXÁ así como a todos los miembros del equipo de investigación que participaron en el I y II Seminarios Internacionales sobre Guinea Ecuatorial celebrados en julio del 2014 y julio del 2015 por sus comentarios a una versión inicial de este texto. La investigación fue posible gracias a una beca recibida por la Universidad de New Hampshire en 2014 y al apoyo prestado por la Cátedra UNESCO de Estudios Afroiberoamericanos de la Universidad de Alcalá de Henares dirigida por Luis Mancha.

271 susucastillorodriguez@gmail.com 
remained unknown for the scholarly work on Equatorial Guinea. As I maintain in this article, the importance of this play rests also on the information she provides about the establishment of the Jamaican Baptist Missionary Society in Fernando Po between 1842 and 1845. Based on Bela Vassady (1979) and Dekar (2001) analysis, this article discuss the role of the Jamaican "native agents" on the Baptist Missionary project as well as its consequences for the colonial British expansion towards the African continent.

KeYwords: Baptist Mission, Fernando Po, Native Agents.

Las vidas de los misioneros, los lugares lejanos hasta donde se desplazaban, las culturas indígenas y el exotismo de los nativos con quienes convivían resultaban fascinantes para autores como Ballantyne, Charlotte Brontë, Herman Melville o Charles Kingsley. Muchos de los personajes de sus novelas estaban inspirados en ellos. El lector británico acogió con interés estas obras que le trasladaban imaginativamente a esos rincones de África o la India y los sacaba de la atonía de la historia local. No solo las novelas, sino también los archivos coloniales están llenos de las historias de estos misioneros, esparcidas por los documentos gubernamentales, los artículos periodísticos, las misivas que alimentaban los informes de las congregaciones, las producciones lingüísticas o los relatos de viajes. Para algunos autores como Spurr (1993), las obras de no ficción escritas por los misioneros permiten una mayor proyección analítica porque según apunta, "often combines [the] metonymic quality with an absence of formal closure, so that it opens directly onto the fractures and contradictions of colonialist epistemology" (Spurr 1993: 2). La obra que aquí presentamos - The Island Heritage (Fisher, 1926)- nos permite, en cierto modo, acercarnos a esos quebrantos entre el proyecto misional colonizador británico y sus resultados; se basa en la reconstrucción teatral en 5 actos de la llegada y establecimiento de la misión baptista jamaicana en la isla de Fernando Póo (hoy Bioko, Guinea Ecuatorial).

En este artículo se combinan dos objetivos. En primer lugar, demostrar que el éxito de las misiones baptistas en Fernando Póo no fue debido al uso de agentes nativos como instrumentos de evangelización sino más bien a, de un lado, las características de las misiones baptistas británicas (fundamentalmente en su componente familiar y en la ideología de su proyecto misionero), y de otro, a la ecléctica y diversa composición étnica y de clase de la sociedad de Clarence en 1841. En segundo lugar, argumentar que el establecimiento de la misión baptista fue punto de arranque y ensayo para la expansión colonial británica hacia 
el interior del continente africano a gran escala. La obra de teatro de Philip. J. Fisher (1926), The Island Heritage nos servirá como base literaria-documental para reconstruir la historia cultural de los misioneros baptistas jamaicanos en Fernando Póo.

\section{The Island Heritage como gramática colonial}

En el campo de la historia, la política, la antropología o la literatura encontramos una abundante bibliografía donde se ponen de relieve las retóricas del discurso colonial que hicieron posible el proyecto colonizador. Un proyecto colonizador que había sido leído en términos de la aplicación de ideas ya definidas sobre la raza y el imperio, en un sentido unidireccional desde el colonizador hacia el colonizado. Los estudios 'neocoloniales' rompen con esta visión de completud del proyecto imperial, criticando lo idealizado de esta trasposición y sus disonancias. Así, a mediados de 1990 surgió un tipo de lectura a contrapelo en los estudios culturales donde se cuestionaba esta predeterminación sin fisuras en la ideología de la colonización la cual remitía, inevitablemente, a una imagen del imperio cohesionada y cerrada. El acento en los estudios de mediados de 1990 se ponía en dos aspectos: de un lado, en analizar las "gramáticas" coloniales, -esto es, los documentos culturales del colonialismo (Gikandi, 1996) - como textos donde explorar los parámetros dentro de los cuales la identidad cultural ("Britishness" o "la espańolidad", por poner un ejemplo) es definida simultáneamente mediante actos de inclusión e exclusión. De otro, identificar las 'categorías coloniales' (Johnston, 2003) así como las retóricas del discurso donde estas se ponen en juego (Spurr, 1993). La conjunción de estas aproximaciones teóricas permitió conceptualizar la cultura de la colonización como un proceso de imbricación mutua (Gikandi, 1996), ya que al cambiar la dirección del análisis desde el colonizado hasta el colonizador y viceversa, la experiencia colonial en los países colonizadores -en su cultura e historia- cambia de perspectiva; se desintegra la historia imperial. Esta se compone ahora no solo del discurso oficial sino también de unas relaciones entre sujetos coloniales complejas, oposicionales y contestadas.

Considero aquí la obra de Fisher, él mismo también misionero, como una gramática colonial donde el escritor occidental articula una representación coherente a partir de una historia contada sobre las extrańas e incomprensibles (para el escritor) realidades que los misioneros baptistas británicos tuvieron que confrontar en el mundo no occidental. Las categorías coloniales sobre las que se basa (jerarquización racial, evangelización, sacrificio en nombre de una misión) permiten poner de relieve cuáles son las presuposiciones culturales, ideológicas 
o literarias que maneja el autor (Spurr, 1993: 3). En un análisis más fino de la 'densidad cultural' de las 'categorías coloniales', se podría hacer un mapeo de los discursos para clasificar genealógicamente los tropos, las figuras retóricas, las categorías conceptuales, las operaciones lógicas y las formas de escribir sobre la población no occidental ${ }^{272}$. De este modo, el enfoque en las producciones literarias misioneras, permitiría, como expone Johnston, abrir un nuevo paradigma en el cual aquellas introducen un cambio en las formas en las que son representadas las facetas cruciales de la cultura del siglo diecinueve. Como resultado obtendríamos una imagen de lo que es hoy el sujeto descolonizado, la identidad del país y por defecto el reflejo la colonización occidental (Gikandi, 1996). No obstante, y a pesar del interés que suscita, este artículo no se orienta a una crítica literaria de la obra de teatro de Fisher ni pretende ahondar en la "imbricación mutua" antes mencionada, lo cual nos llevaría a interrogarnos sobre cómo los fernandinos (población criolla resultante del poblamiento de Clarence con personas de la costa de Biafra) reconstruyen hoy día su identidad cultural, lingüística; cuál es su discurso sobre la diáspora; en qué grupo étnico guineoecuatoriano se inscriben (llegado el caso); si reivindican una historia común con Gran Bretaña y de qué tipo; cuál ha sido su herencia religiosa y cómo se manifiesta hoy día ${ }^{273}$. Se trata más bien de hacer una reconstrucción de la historia cultural de la colonización misional británica en Fernando Póo, y de poner de manifiesto cómo la prosa en The Island Heritage es una representación del proselitismo misionero británico en tanto que hace efectivo y ofrece, como dice Johnston, "a modelo of 'civilised' expansionism and colonial community management, transforming imperial projects into moral allegories" (Johnston, 2003: 13). Ello se justifica por la importancia que tiene la obra en varios niveles: histórico, literario, misional, antropológico. The Island Heritage:

Es un producto colonial equiparable a los de exploradores, misioneros, administradores coloniales, cuando escriben la historial imperial (en este caso de Gran Bretaña).

272 Spurr apoyándose en lo que Derrida denomina "the anthropological war" analiza las siguientes doce formas retóricas: surveillance, appropiation, aestheticization, classification, debasement, negation, affirmation, idealization, insubstantialization, naturalization, eroticization, resistance (Spurr, 1993). Ello le permite presentar un sistema en el cual una cultura interpreta, representa y domina -finalmente- a otra.

273 El desarrollo de esta línea analítica requiere de un trabajo de campo prolongado, cuya etnografía responda a estos interrrogantes, algo que contemplo para una investigación futura. Sobre un trazado histórico-cultural de los fernandinos, véase Sundiata, 1975; 1996). 
Engrosa el archivo colonial como un informe de la política interior, exterior y misional británica.

Constituye una producción misionera, no solo por sus personajes sino por ser el mismo Philip. J. Fisher capellán de la iglesia metodista primitiva.

Permite analizar categorías de raza, clase social, género, lenguas colonizadoras y nativas, así como la ideología moral y religiosa de la época.

Ha permanecido incógnita en el análisis literario y en la bibliografía sobre la colonización de Guinea Ecuatorial.

\section{Algunos datos sobre la obra}

The Island Heritage. Episodes from the missionary history of Fernando Poo, West Africa. A play for young people, es según nos revela el autor en el título, una obra de teatro destinada a la población adolescente. Publicada en 1926 en Londres, poca información tenemos sobre el autor a excepción de los datos localizados en internet. Phil. J. Fisher nació en Maidenhead en 1883 y murió el 6 de julio de 1961. Se formó como ministro en Hartley College, Manchester, UK y desde 1905 hasta 1945 se desempeñó como capellán en varios circuitos (como Liverpool o Middlesborough). Su historia como capellán está íntimamente relacionada con la creación de 'The United Army Board' y su trabajo en los frentes de batalla durante la primera guerra mundial. La iglesia metodista primitiva se unió a la baptista, congregacional y metodista para formar 'The United Army Board' cuyos capellanes proveían de servicios religiosos a las tropas. De los 72 que fueron nombrados en 1915, 13 eran de la iglesia metodista primitiva. Fisher no solo parecía tener vocación religiosa; además de su faceta como escritor, era también dibujante. En 1917 publicó Khaki Vignettes, con el subtítulo "Six Months Chaplain to the Troops in England and Fifteen Months in France". Las viñetas son dibujos hechos a lápiz, donde se representa la vida de los soldados en el campo de batalla, en sus tiendas, en vivac, departiendo con otros soldados y con el capellán. El apartado "Cheerfulness of the lads" [la alegría de los chicos] se orientaba a levantar el ánimo de quienes tenían hijos combatiendo en el frente:

"If you, my chance reader, [escribe Fisher] can gather from it some lively impression of the joys, the toils, the deeds and sufferings, the heroism and the amazing cheerfulness of the British lads in khaki - the lads from our Churches and congregations - your own lads, maybe - then I shall feel that this book, 
imperfect as it is, was worth the making" (consultado el 19 de junio de 2015 http://www.myprimitivemethodists.org.uk/).

Como escritor, aparte de The Island Heritage, Fisher escribió, según se recoge en el título de la misma, "The opening of the door" aunque no he encontrado ninguna referencia a esta obra.

The Island Heritage abre con un listado de los personajes: 21 protagonistas divididos entre 13 hombres y 8 mujeres. Le sigue una introducción donde Fisher expone porqué se interesó en Fernando Póo "There is the cocoa-farming, for instance, and the education struggle, and the minister to the polyglot indentured labourers by means of the quaint Kroo-English." Pero fundamentalmente señala los motivos que le llevaron a centrar la temática de su obra en base a la historia de la obra misionera baptista en Fernando Póo: el impacto colonial que tuvo la misión en la costa occidental ("it was the historical line which fascinated me, particularly the persistence of the vision of extension to the West Coast, of which the recent advance into Okpoto [cerca de Enugu, Nigeria] is the latest fruit.", escribe Fisher). Este aspecto es fundamental, como ya apunté, para entender la historia de la colonización británica y misionera baptista en Fernando Póo, así como para enmarcar el contexto de producción de la obra de teatro. El título "The Island Heritage" aparece en una especie de dilogía que apunta tanto a la herencia cultural, religiosa, material, política y humana que dejaron los misioneros baptistas en la isla de Fernando Póo (según vimos anteriormente con la población criolla fernandina), como recíprocamente en cuanto es el legado de Fernando Póo en la historia colonial británica. Este no fue resultado de una mera explotación de recursos y de su productividad geográfica (usando Fernando Póo como punto de control del tráfico de esclavos en el Atlántico); su huella se extendió hasta la parte continental de Nigeria y Camerún, donde se adentraron los británicos desde su base en Clarence.

La obra de teatro está dividida en 5 actos. En el primero, Fisher hace una reconstrucción fiel -según la historia- de la llegada del reverendo baptista británico Clarke y del doctor Prince a Jericho (Jamaica) y su posterior regreso a Fernando Póo, esta vez con el reverendo Merrick y un grupo de familias jamaicanas ${ }^{274}$. En los actos siguientes, Fisher va introduciendo nuevos personajes, entre

274 Fisher se refiere a estas familias como "native families" adoptando el lenguaje y la ideología de la época sobre la eficacia de los "native agents" como estrategia en la evangelización. Abundaré sobre ello más adelante. 
ellos al capitán del barco Elgiva WM. Robinson, al reverendo Henry Roe (misionero de la iglesia primitiva metodista) y su esposa, Mamma Nicolls y Mamma Job ("native widows"), Rosa and Ria ("native maid to Mamma Nicolls"), Tim ("a native house-boy"), Yellow Will, (“a krooman”), reverendos Robert Fairley y J. Marcus Brown ("missionaries at Santa Isabel”), reverendo W. Norcross y su esposa ("missionaries at Igumale, Nigeria”), Jessie (“a native girl”) y Jerry (“a native interpreter"). A tenor de la introducción, Fisher se basó en documentos y en información de primera mano provista por el rev. Henry Roe y Mr. Norcross ${ }^{275}$. La obra de teatro se podría caracterizar de estilo propagandístico, donde se ensalzan las proezas de los misioneros, engrandeciendo su figura como una persona honesta, con vocación evangelizadora, creíble, sin crisis identitarias y sobre todo, familiar. El objetivo no sería tanto identificar la verdad y dar a conocer las penalidades y dudas por las que pasaron sino examinar las vías por las que la experiencia puede ser narrada de forma creíble y consistente (Johnston, 2003). Y en este intento por representar la realidad lo más fielmente posible, Fisher introduce el modo de habla de Mamma Nicholls y Mamma Job, un "Broken English" que es transcrito en su pronunciación literal. En la escena III Mamma Nicholls cuenta la historia de su llegada a Fernando Póo y Fisher, en una acotación al discurso, describe la reacción de los misioneros:

"Mammy Nicholls: me heart berry full. Lor' jesus do so much fo' me. Me lib ober dey-dey in big country. Me young gal. bad men come, kill plenty people, take me away fo' slabe-ship, fo' sell me fo' slabe. Me sad, sad, sad, too much. Den de good English ship come, bring me here F'nando POO, make me fo' go free. Me lub de English fo' make me free woman. Me plenty glad fo' see you sarbants o' Jesus. Praise de lor'! me be berry good o you - do every-ting fo' sarbe you. Oh, me no fit lib pass I lub de lor', pass I sarbe Him!.

275 Escribe Fisher en la introducción: "A portrait of Capt. Robinson appeared in the Liverpool Conference Handbook; others - as of Mamma Job and TR Prince - may be found in some of our missionary publications (eg. Rev. N. Boocook's Our Fernandian Missions) (...) My grateful acknowledgments are due to a number of generous helpers - to the Rev R. W, Burnett (the infant of scene III) for the loan of valuable books, now out of print, by Hery Roe, some Baptist Missionary publications, the first volume of our Missionary Records, etc,. and for much information; to the Rev. R. Fairley for the use of his scrap-books and other useful help; to the Rev, W. H. Collins, who generously handed over to me all his notebooks, and to whom I am chiefly indebted for the "principles" of kroo-English; and once again to my ever -responsive friend Clement Gerrard for revising the musical pages". 
[ all this very passionately, movingly spoken. Missionaries - to whom this broken English is strange, listen very intently, with puzzled expressions, but trying to look as if they understand. Mrs Roe really does catch the drift of it]"

El autor da muestras en la introducción a la obra de una sensibilidad sociolingüística que pretende alejarse de prejuicios sobre la 'corrupta' forma de habla del pidgin ("Kroo-English"), y advierte al lector y actor que no se deje llevar por lo pintoresco del idioma: "Care should be taken not to burlesque the honouree native character in scene III. The speech is quaint, but the emotions are sacred".

Por último, para cerrar este apartado sobre la obra, cabe mencionar que viene acompañada de unas notas sobre la pronunciación de los nombres y su significado $^{276}$ así como de un poema con sus notas musicales a modo de prólogo para que sea cantado por un coro.

\section{La Sociedad Misionera Baptista en Inglaterra y Jamaica}

Los años de 1800-1860 fueron críticos para la reforma social en Gran Bretaña, "where many cultural narratives central to British self-imagining were (re) invented" (Johnston, 2003: 4). Fue el momento de la revitalización de la religiosidad británica cuando los movimientos filantrópicos, más independientes del 'establisment' de la Iglesia de Inglaterra, florecieron. Ello dio lugar a nuevas concepciones sobre raza, clase, género, otras culturas, antes del imperialismo de fin de siglo, donde estas ideas ya estaban más cerradas. Obras como la de William Carey An Enquiry into the Obligations of Christians, to Use Means for the Conversion of the Heathens (1792) fueron el detonante en la fundación de la "Particular Baptist Society for Propagating the Gospel among the Heathen (paganos)" - The Baptist Missionary Society (en adelante BMS)- en Kettering, a 80 millas de Londres ${ }^{277}$. En las indias orientales, Dr. Thomas Coke publicó su Plan of the Society for the Establishment of Missions among the Heathens en 1783 y fundó allí la primera misión metodista. La financiación de la misma recaía

276 Destaco por ejemplo la nota de Fisher sobre una expresión que usan Mamma Nicholls y Mamma Job: “'so-tee-ee-eh' this is long drawn out. A graphic Kroo expression for 'until' conveying the idea of a very long time"

277 Entre los objetivos de la BMS, además del trabajo pastoral y evangélico, estaban la educación, la traducción, la salud y los beneficios sociales. 
en sus fondos personales y no fue hasta 1813 cuando en el distrito de Leeds se formó la primera Wesleyan Methodist Missionary Society para financiar estos proyectos. Más tarde, The London Missionary Society, daba también cuenta de la unidad cultural e ideológica que atravesaba el país y profesaba la unión de calvinistas y arminianos y baptistas bajo una misma congregación (Brian Stanley, 1990: 56 ${ }^{278}$. Las misiones protestantes se expandieron en África y en las Indias orientales y Occidentales con mayor o menor éxito.

Tras los primeros fracasos en Sierra Leona y Níger, y lejos de un posible estancamiento, el impulso de la política colonial británica se estaba fraguando al otro lado del atlántico, en las indias occidentales. Fue allí donde la influencia de los baptistas había ido creciendo desde el siglo XVIII gracias a los movimientos de esclavos que se propagaban desde Georgia (Estados Unidos) hacia las islas. Los primeros baptistas entraron en Jamaica como consecuencia de las evacuaciones de Charleston y Savannah durante la guerra de independencia americana, en $1776^{279}$. La misión se inicia como intento de trabajar entre los esclavos de las colonias azucareras, compuesta fundamentalmente por descendientes africanos. Sin embargo, los baptistas chocaron con varios frentes: de un lado se prohibió la enseńanza de la doctrina cristiana en las plantaciones de esclavos en 1806. De otro, había conflictos internos entre quienes pensaban que la esclavitud era parte del sistema político y quienes lo consideraban un demonio social que había que aniquilar. Andrew Fuller, secretario de la Sociedad Baptista escribió en 1811 que la esclavitud no era mala en sí misma (Russell 2000: 11). A pesar de ello, los primeros misioneros que mandaron a Jamaica fueron avisados de que "it is not for you to interfere in political matters" ("The Register, vol 1pp. 270/9. 1791, cfr. Russell 2000: 12). Además, había fricciones entre las leyes de las metrópolis y las leyes locales, por ejemplo con las compañías azucareras que allí funcionaban. La influencia de la iglesia baptista creció exponencialmente hasta ser decisiva en la aprobación del Emancipation Act en 1833. Un año más tarde, los esclavos del Caribe también fueron declarados libres.

Tanta simpatía y admiración despertó el trabajo de los baptistas en la abolición de la esclavitud, que fueron muchos los liberados africanos que se unieron a

278 Ya desde 1799 los evangélicos anglicanos habían fundado su propia sociedad "the Society for Missions to Africa and the East" conocida desde 1812 como the Church Missionary Society.

279 El africano George Liele (o Lisle), baptista y procedente de Georgia (EEUU) fue el primero en predicar entre los esclavos africanos en Jamaica. Le siguió John Rowe, estudiante de la Baptist Missionary Society en Inglaterra (Salomon N. Gwei 1966: 1) 
su causa. La Jamaican Baptist Missionary Society (en adelante JBMS), se separó de la BMS en 1842 funcionando de manera independiente tanto en recursos económicos como humanos ${ }^{280}$ (Jamaica and Cameroons Missionary Papers. mundus.ac.uk. Consultado en mayo de 2015). Es importante destacar aquí dos aspectos de la misión jamaicana (Jamaican Baptist Missionary Society (JBMS)): primero, su criollización y segundo, su interés en África. Respecto al primer aspecto, ya hemos apuntado que muchos de los misioneros que se unieron a la JBMS eran esclavos africanos liberados; el primer ejemplo fue el de Thomas Keith ${ }^{281}$, que tras su emancipación vendió todo lo que tenía y se embarcó hacia África. J. Clarke (reverendo baptista inglés y destinado como pastor de la Jericho Baptist Church en Jamaica) y el doctor G. K. Prince (antiguo dueño de esclavos), partieron en misión exploratoria a Níger y acabaron en Fernando Póo en $1841^{282}$.

La explicación del entusiasmo entre los africanos liberados por pertenecer a la iglesia baptista se basaba en el atractivo de lo que los misioneros representaban: el éxito de su emancipación. De ahí que la teología de la misión jamaicana estuviera basada en dos principios: compensación y gratitud (Russell, 2000: 115). Con el incremento de recursos humanos y económicos que provenía del agradecimiento, la JBMS se embarcó desde el comienzo en una política de formación religiosa y educativa entre sus miembros, desembocando en un mezcla

280 The 'apprenticeship for Jamaican projects' recibió ayuda del Ladies Negro Friend Society. Según algunos documentos de la época, "Birmingham was at the centre of one of the earliest, one of the longest running, and one of the most significant of Britain's numerous nineteenth century women's antislavery societies. "The Female Society for Birmingham, West Bromwich, Wednesbury, Walsall, and their Respective Neighbourhoods, for the Relief of British Negro Slaves" was officially founded in 1825 by Lucy Townsend and Mary Lloyd. This was a year before the all male 'Birmingham Anti-Slavery Society' was established. Like the men, they were indebted to non-conformist religious views such as Quakerism. Unlike the men however, their official position was to raise charity funds to relive suffering, rather than to exist as a 'political' organisation. Undermining this distinction, some of the women's views on slavery were often highly radical, as can be seen by Elizabeth Heyricks' call for 'immediate abolition' expressed as early as 1824. http://www.connectinghistories.org.uk/ Learning\%20Packages/Anti\%20Slavery/antislavery_Ip_03.asp (consultado el 18 de junio de 2015).

281 La referencia es de mundus.ac.uk pero según se cita en el libro de Buxton, el nombre podría ser James Keats y no Thomas Keith (Buxton 1840: 495)

282 Nótese que las fronteras geográficas difieren de las actuales y que a Fernando Póo (hoy Bioko) se le clasifica dentro de "The Cameroons". The Cameroons abarcaba desde el río de los Camarones por la costa hasta el Río Muni (véase en anexo el mapa de S. Nfor Gwei, 1966) 
radical en sus congregaciones ${ }^{283}$. Bien es sabido que Jamaica era por excelencia una ciudad diversa, compuesta mayoritariamente por africanos procedentes de toda la costa del golfo de Biafra. En consecuencia, esta criollización no tuvo más remedio que reflejarse en la política de captación de futuros reverendos, quienes eran bien acogidos por la creencia de que estaban en mejor posición para predicar el evangelio entre personas de su mismo origen.

El interés en África, como segundo aspecto de la misión jamaicana, atiende a varias teorías. Está por una parte el deseo de retornar a África, de volver a la 'tierra madre'. Está también el objetivo de continuar en África el trabajo de lucha contra la esclavitud que con tanto éxito se había llevado a cabo en Jamaica: "They saw no better way of expressing their gratitude to God for their freedom than by carrying the gospel to those in the lands of their forefathers who were still living under the yoke of pagan superstition" (S. Nfor Gwei, 1966: 2). Estos objetivos se fundían con los de la misión de la BMS en África occidental, los cuales buscaban crear "a blend of civilization, commerce and Christianity as the medicine for Africa's sickness" ("Slavery. The Historical and Modern Perspectives" en The Angus Library and Archive, theangus.rpc.ox.ac.uk 2013. Consultado en mayo de 2015) (las cursivas son mías). Señalo aquí cómo los occidentales entienden la "enfermedad" de África por su paganismo pero también por representar el yugo de la esclavitud. Como respuesta a una carta enviada por un ministro baptista en Jamaica ${ }^{284}$ al secretario de la BMS preguntando por la posibilidad de una misión en el interior del África occidental, Buxton, miembro del Parlamento británico y líder del movimiento de antiesclavitud, responde:

"...the land from which the beloved people of our charge, or their forefathers, were stolen, and which is at present without the light of the gospel, and suffering under accumulated wrongs. We, the ministers, feel on this subject an intense interest, while in their hearts the strongest emotions are excited for the perishing land of their fathers. The conversion of Africa to God is the theme of their conversation and their prayers, and the object of their most ardent desires. (...) some are anxious to go themselves, and

283 Buxton (1840: 516) se hace eco de ello: "In 1835, the Moravians contemplated a plan for establishing an institution in Jamaica, 'for training native missionaries and teachers for needy Africa”'. Los moravians eran una comunión protestante estrechamente vinculados con el luteranismo. Desde 1735 fundó iglesias en Georgia, Pensilvania y Carolina del Norte.

284 Es probable que fueran los baptistas jamaicanos Henry Beckford y Edward Barrett (Dekar, 2001: 435) 
proclaim to their kindred the love of Christ in dying for their salvation" (Buxton 1840: 493).

Reforzando este argumento, el reverendo de la Iglesia baptista de Jamaica, Joseph Merrick, él mismo un negro emancipado y personaje principal en la obra de Fisher, decía lo siguiente en la reunión anual de la BMS en 1843: "The very night that liberty was proclaimed in that land -the night that the yoke was broken from their necks, that their shackles were snapped asunder- they resorted to the house of God to bless him for temporal liberty, and that very night fully resolved that Africa, their fatherland, should be blessed with the gospel" (Missionary Herald July 1843 pg 126f. Cfr en S. Nfor Gwei, 1966: 2).

Además de estas teorías hay quienes interpretaban el deseo de retorno a África como un 'revival' de las profecías del Nuevo Testamento. Los africanos esclavos en Jamaica eran equiparados a las víctimas del Éxodo y del Exilio del pueblo de Israel según la Biblia. Considerados como 'poor Ethiopians' para Russell (2000:72) "...the fact that there were, 'Eboes, Mandingoes, Congoes and other nations' receiving instructions in order to return to Africa was a proof enough of a providential design. In this mind emancipation was a new exodus and Africa was a new Canaan" (las cursivas son mías). En definitiva cabe señalar que todas estas teorías confluyen en lo que antes apuntábamos: el despegue de la JBMS en África estuvo impulsado por el deseo de saldar la deuda (esto es, la contraparte del agradecimiento por la abolición de la esclavitud) participando como instrumentos en la evangelización y conversión de los paganos. Para ello, la condición de "hermanos" entre quienes fueron llevados a Jamaica y los africanos se observaba como el medio más eficaz.

\section{Los jamaicanos como agentes nativos}

La African Civilization Society fue creada para la evangelización de África a través de agentes nativos (Carta desde Kingston, Jamaica 1839 y citada en Buxton 1840: 494). La idea de usar "native agents" ("native missionaries, native schoolmasters, native teachers, native interpreters", "colonizers") como "brokers" en la evangelización y civilización de los africanos quedó plenamente desarrollada en el libro de Buxton The African Slave Trade and its Remedy (1840) donde le 
dedica un apartado titulado "Agents to be obtained". Buxton abre este debate diciendo:

"I have a great satisfaction in finding, that from among the liberated Africans in our West Indian Colonies, we are likely to be furnished with a number of persons, in whom are united the desirable qualifications of fitness for the climate, competency to act as a teachers, and willingness to enter upon the work" (Buxton 1840: 492).

Y más adelante (Buxton, 1840: 495-497) refuerza su posición aportando una serie de propuestas recibidas desde Jamaica e Inglaterra para el reclutamiento de "an agency of negro and coloured persons". Para justificar sus planteamientos los reverendos subrayan la "good common education" entre los agentes nativos, su capacidad para ser entrenados en la escuela de la Church Missionary Society en Inglaterra y porque esta medida parecía "very feasible and comparatively inexpensive" 285 .

El caso de la JBMS en Fernando Póo no puede ser más ejemplar. Todos excepto Clarke y Dr. Prince (su esposa tenía descendencia africana) habían nacido en Jamaica. En la primera escena, Fisher desarrolla un diálogo ${ }^{286}$ para ilustrar la motivación que tendrían los “agentes nativos" para desplazarse a África:

Mrs Merrick: (...) Over three years ago now, you remember, we in Jamaica sent a memorial to the Committee at home, urging them to mission Africa.

Clarke: Yes, (...) and it was our own coloured folk, stirred by the Spirit of god to a passionate concern for the land from which they were unrighteously torn, who cried out for it. Let that honour be theirs, whatever the future may bring.

285 En 1841, la reunión anual de la BMS se centró en presentar los avances de la misión en Fernando Póo. Rápidamente la discusión fue monopolizada por Vaugh quien mantuvo que la misión confirmaba el "Designio Providencial" sobre los misioneros negros: "He argued -escribe Russell sobre ese momento- that it was patently obvious that black missionaries appreciated more readily African modes of thought better any white men could and furthermore, in his words, "they alone can brave the climate effectively"' (Russell, 2000: 114).

286 Curiosamente es entre la esposa de Merrick y Clarke, quizá para reforzar el carácter de la misión baptista, dirigida por hombres casados que se trasladan con sus familias a África. 
Prince: yes, it has been born of the patriotism of the Cross! and may its portent be realized -the evangelization of Africa by Africans!

La trayectoria de los baptistas y jamaicanos a Fernando Póo fue como sigue: en octubre de 1840 Clarke y Prince partieron en misión a la costa de África, pasando por Cabo Palmas y la Costa de Oro. Llegaron el 1 de enero de 1841 a Port Clarence y decidieron quedarse ya que el barco no les llevaría a Níger. En Port Clarence (la parte antigua de Malabo) se encontraron que sus 700 habitantes eran esclavos libres que hablaban inglés como lengua franca; los "adeejahs" (bubis) rondaban entre los 5.000 y los 10.000 en toda la isla ${ }^{287}$. Tras un año de exploración ${ }^{288}$, cuando retornaban a Inglaterra, el mástil del barco se rompió y fondearon en Falmouth, Jamaica ${ }^{289}$. The Island Heritage empieza en ese preciso momento, cuando todos se encuentran en la casa de Joseph Merrick, un jamaicano convertido por Clarke quien le sucedió como pastor en la Jericho Baptist Church cuando éste partió a África en $1840^{290}$. Tanto Merrick como Alexander McCloud Fuller y su hijo Joseph Jackson Fuller -además de la esposa de Merrick (Elizabeth Knowles Merrick)- fueron con G. K. Prince a Fernando Póo en 1842.

287 Es difícil dar un número exacto de la población en Fernando Póo. Las estimaciones oscilan entre 900 krumanes en Clarence y un total de 15.000 bubis en toda la isla en 1842 (Schön y Crowther 1842: 246-248). Para el total desagregado de la población en Clarence, véase el anexo con el censo de Hutchinson (1858). Unzueta (1947: 286) aporta también un censo elaborado por el Gobernador de Fernando Póo José de la Gándara en 1869 donde se registran 1.223 habitantes en Santa Isabel más 120 hombres y 30 mujeres 'congos emancipados de la Habana' . El nombre de 'congos' es una sinécdoque para los afrocubanos que llegaron en 1862. Para más información sobre este episodio en la historia de Fernando Póo, véase Castillo-Rodríguez (en prensa). Al final de la escena II de la obra de teatro, Prince dice que hizo un censo de los esclavos recogidos de los barcos negreros y que ahora habitaban Fernando Póo.

288 Según los informes de Clarke al Missionary Herald, el 15 de noviembre de 1841 bautizaron a Jonh Christian, Phoebe Christian, Joseph Wilson, Peter Nicolls y Mary Ann Burco, quienes formaron la primera congregación bautista en Fernando Póo. Al poco tiempo, se pusieron en marcha la escuela dominical y las clases sobre la Biblia (S. Nfor Gwei, 1966: 14).

289 Desde allí viajaron a Inglaterra con Joseph Merrick y Alexander Fuller donde dieron cuenta del éxito de la misión en Fernando Póo y reclamaron el envío de agentes nativos.

290 Joseph Merrick, hijo de Richard Merrick era una persona bien educada y al parecer se le daban bien las lenguas por lo que se dedicó a aprender el isubu y el duala en su llegada a Camerún. Tradujo al isubu las escrituras y predicó en ambas lenguas. Fue aprendiz de imprenta y editor de un periódico sobre antiesclavitud. (Bela Vassady, 1979: 17). Clarke lo clasifica como "cuarterón" (Nacido en América de mestizo y española, o de español y mestiza, según la RAE) y lo describe como "sufficiently fair to pass for white persons in any country where such distinctions do not prevail” (Bela Vassady, 1979: 18). Alexander Fuller fue maestro en la escuela dominical 
Un año más tarde llegaron Clarke y Alfred Saker con sus esposas, varios misioneros británicos, y 37 colonos y maestros, cuidadosamente clasificados por Clarke como "white -by-law", "coloured", "coloured-creole", "mulatto" (Bela Vassady, 1979: 18 ${ }^{291}$. Aunque la orden de las autoridades españolas para que abandonaran la isla se dio en 1845, hasta que Carlos Chacón no circunscribió la práctica de otra religión fuera de la católica al ámbito privado en 1858, unos pocos baptistas se mantuvieron en Fernando Póo ${ }^{292}$.

¿Cuál fue pues el impacto de los agentes nativos? ¿Fracasó o tuvo éxito esta política? Tanto Bela Vassady como Dekar abundan en esta cuestión y coinciden en el éxito inicial de la misión. Crearon una congregación de 44 miembros, y muchos estaban interesados en la escuela dominical. Esos 44 miembros, como apuntábamos, pertenecían a la población fernandina de Clarence; eran esclavos libres llegados con Owen desde la costa africana, acostumbrados a la administración británica, sus costumbres y al uso del inglés como lengua franca. Sin embargo, los baptistas descuidaron el trabajo con los colonos jamaicanos que llevaron, quienes pronto se dieron cuenta de las dificultades que entrañaba el "revival" de África. Estos agentes nativos jamaicanos que fueron como colonos habían recibido educación en Jamaica, llegaban con unas expectativas de estilo de vida y comodidades que no encontraron en Clarence. Formaban una élite comerciante y cultural a la europea, y fueron incapaces de ajustarse a las casi inexistentes condiciones de vivienda, los bajos salarios o el clima. Ni siquiera la supuesta adaptación física o la pretendida familiaridad con las lenguas les fué útil. Los jamaicanos morían en igual número que los europeos y no se acostumbraban al clima. Además competían con los fernandinos, quienes eran escogidos en mayor proporción como ayudantes en la misión. Los jamaicanos fueron sintiendo con más fuerza la jerarquía que los separaba de los británicos; el peso de su actitud proteccionista y la ausencia de la ayuda económica desde Inglaterra. La supuesta igualdad con los británicos y la creencia entre los jamaicanos de que

291 La sociedad jamaicana estaba muy concienciada acerca de las diferencias de color. Para un mayor desarrollo de la división hacia la "blancura" (mulatto, terceroon, quadroon, mustee, musteefino) véase Bela Vassady, 1979: 34 nota 18.

292 Fisher recoge esto en la escena II, ambientada en 1869, cuando Prince, un comerciante nativo de Sierra Leona, educado y hablante de un "almost correct English, very different from the "pidgin" spoken by some of the later characters -unless he is speaking to some of these, when he sometimes adopt their idiom" explica la retirada de los misioneros baptistas a Congo. 
estaban bajo su protección se probó errónea; a los efectos, los jamaicanos seguían siendo "negros" frente a los blancos. A todo ello se sumó que sus expectativas de crear una nueva y mejor vida en África no se cumplieron. Los jamaicanos habían sido llevados como colonos y maestros, "agentes nativos" bajo la premisa de ser una élite que haría realidad la misión baptista de promover comercio y civilización con sus vidas ejemplarizantes: "They disciplined members who stayed and routinely called people to prayer, and spiritual revival, purification, and humiliation" (Dekar, 2000: 436).

En este ambiente, el intercambio de correo "untrue and exaggerated" según Bela Vassady, 1979: 27, entre los baptistas en Fernando Póo y la BMS se intensificó. En diciembre de 1845, la misión baptista fue compelida a abandonar la isla con el ofrecimiento de tres opciones: mudarse a Bimbia, permanecer en Clarence restringiendo el culto al ámbito privado o retornar a Jamaica. La mayoría de los maestros jamaicanos optaron por regresar a Jamaica y pidieron a la BMS que les pagara el pasaje. Los colonos jamaicanos, en contraste con los "coloured teachers" supieron ajustar sus expectativas a las de los europeos de Fernando Póo y se adaptaron a las condiciones de vida por lo que aceptaron marcharse a Bimbia en $1846^{293}$. Concluía así la experiencia de los "agentes nativos" de la JBMS en Fernando Póo.

Para cerrar esta sección, retomo aquí lo que apuntábamos al comienzo sobre cual fue el otro pilar en el éxito de los baptistas jamaicanos en Fernando Póo: el que se encontraran con una población diversa (krumanes, que criollizados compondrán la sociedad fernandina), medio aculturada en las costumbres europeas, que hablaba la lengua y abrazaba el proyecto civilizador-evangélico de los misioneros, semejante a la que habían dejado en Jamaica, y donde habían cuajado de inmediato. En el informe del reverendo George Bell, de la Primitive Methodist Missionary Society describe la sociedad de la siguiente forma:

293 La explicación de fondo, sostiene Bela Vassady (1979: 29), es que el sistema social jamaicano presiona a los "coloureds" (agentes nativos como maestros) a competir con los blancos mientras que los negros (aquí colonos) se refugian en su propia identidad cultural y dejan a un lado los dilemas que suponen no ser ni lo uno ni lo otro (ni blanco, ni negro). Esto se vio reforzado en África, donde las relaciones entre blancos y negros fueron más amigables que entre las relaciones "white-coloured", según vimos con la prohibición de los matrimonios mixtos. 
The labour supply has been mainly from three areas. From Liberia come people of two tribes, Mendi and Bassa. Many of these have been influenced our church and several are now really good church workers, especially at San Carlos. They are vigorous and intelligent people. From Spanish Guinea come three tribes, Combe, Buseba and Pamue. The combes and busebas come from the coast and a few miles inland; the pamues well back in the interior. The pamues are a vigorous people, but the rest are for the most part much weaker in every way. We have had people from these two areas throught the recruiting activities of the Spanish government. There is a third area- the Cameroons from which we get labourers and others. These come mainly from three tribes. Douala gives its name to a tribe at the northern end. Yaunde, which the French have made the capital of the colony, is well inland, east of Douala, and names another tribe; while south of Yaunde are the Balus....the American Presbyterian Mission works among these Cameroon folk, and we get many into our Fernandian churches, but almost all return to their own home after a few years ${ }^{294}$. (The Adventure of the Road. vol. 1928: 71. En Popular Report of the Primitive Methodist Missionary Society. 5. vols. George Ayre 1928-1932).

Las descripciones de esta población llegada de las costas africanas difieren mucho de la población indígena bubi. No solo se comparan físicamente, sus costumbres, sus formas de vestir y los ornamentos que llevan en la cabeza, (caracterizados como "peculiares" y "curiosos"; ver Owen 1833: 197-199; Schön y Crowther 1842: 249-250), sino también -y es lo que aquí nos interesa más-, su distinto grado de exposición a la 'civilización europea'. Frente a los krumanes y esclavos libertos, los bubis se presentan como una etnia aislada y salvaje. Así lo escenifica Fisher en la escena III, en un diálogo entre Clarke, Prince y Merrick:

Clarke: The natives are called adeeyas, or some call them bubis. They are a simple and good-natured tribe, of friendly disposition, but their condition is very pitiable. They are almost naked and live in miserable huts, while their religion seems to be a kind of devil-worship, full of the most horrible superstition.

294 El traslado de población desde la costa africana a Fernando Póo no era bien visto por todos: El reverendo J. H. Briggs comenta que tiene sus peligros ya que los hombres deben dejar sus mujeres atrás lo cual tiene un efecto negativo sobre la moral de los isleńos y de los migrantes mismos. 
Besides the bubis, however, there are in Clarence, which is where our mission station is located, a number of people from various coast tribes. Many of these were slaves, rescued by our navy from the slave-traders. Dr. Prince made a census of their tribes last April.

Prince: They represent 26 different tribes from the mainland or other islands. There are a good number of them ibos, who belong to the Niger country, and still more are kroos. This is particularly interesting because we have so many of these tribes in Jamaica. I believe at Salter's Hill alone we have about 130 of the ibo tribe and quite a few kroos.

Merrick: A most interesting link - and surely an opportunity, for if these can be won for Christ they can become messengers to their own people in the mainland.

Clark: That is our hope. Moreover, some of these folk from the coast who are not ex-slaves have formerly had some touch with Methodist missions in sierra Leona and elsewhere, so that the gospel is not entirely strange to them, and some can read and write and speak a sort of English.

Los africanos llegados a Fernando Póo previo al establecimiento de la misión habían entrado en contacto con las misiones baptistas por sus previas expediciones por el Níger, y asistían ahora a sus servicios religiosos y de alfabetización en Fernando Póo. Al respecto Schön y Crowther (1842: 247) comentan que mientras para los krumanes "There is a day-school at the place, kept by a young man from Cape Coast, who obtains his livelihood by giving instruction. The school is attended by forty or forty-five children of both sexes" (Schön y Crowther 1842: 247), entre los bubis "little progress has been made in civilization: they are satisfied with their own habits and customs, which are by no means commendable" (Schön y Crowther 1842: 249). La misión baptista no tuvo impacto en la población nativa bubi. No fue así con la población criolla y The Island Heritage da buena cuenta de ello en las escenas III-V cuando Mama Nicolls y Mama Job prodigan su agradecimiento a los británicos y rechazan la soberanía española:

Mamma job. Yas, F'nando poo, yas! And plenty, plenty more place in Africa no sabby de true word 'bout jesus. [with hands over her breast] me Ibo-me took for slabe, all same like Mammy nicolls. But de English sabe me. Yas, t’ank de lor' 
fo' de English! Me English subjec' massa roe [very proudly] - me no Spanish! Ober dey-dey [pointing towards window] plenty, plenty me peoples no sabby not'ing 'bout dere Sabiour. S' pose bime -bye more missionaries come, den dey go fo' me ibo people-change dem hearts from bad fashion? Dat be plenty fine t’ing, massa Bawnett.!

Así las cosas, los baptistas vendieron el 'éxito' de la misión a los superiores en el gobierno británico, quienes dieron carta blanca para la penetración y colonización de la parte continental africana desde la "base" fernandina.

\section{Fernando Póo en la política colonial británica}

Desde mediados de 1750, según Lynn (1990), la política exterior británica en África occidental se había basado en el interés por el comercio de esclavos entre las compañías mercantiles (como la Company of Merchants Trading to Africa). Ejemplo de ello fue la Sierra Leone Company en Freetown. La abolición del comercio de esclavos en 1807 supuso una mayor intervención gubernamental y un conflicto doméstico entre partidarios y detractores. Las condiciones climáticas y sanitarias de Sierra Leona la convertían en una tumba para los europeos y el coste humano y económico del control del comercio de esclavos no parecía ser rentable. Entre los intelectuales que abogaban por la retirada de Sierra Leona y aquellos que promovían un cambio de estrategia se encontraban Thomas F. Buxton, jefe de la sección parlamentaria antiesclavista y autor del influyente libro The African Slave Trade and its Remedy (1839; 1840), según hemos apuntado. Buxton emergió como un intelectual decisivo en la política británica colonial delineando sus tres pilares: comercio, civilización y cristianización. Para hacer efectiva su política Buxton consideraba que era necesario encontrar un punto de entrada hacia el continente, una vez descartada la penetración por Sierra Leona. A partir de aquí, la historia de Fernando Póo es, en cierto sentido, el microcosmos de la política colonial británica. Esta se inicia ya en 1819, cuando G. A. Robertson, comerciante con oro, propuso ocupar la isla de Fernando Póo por su posición estratégica en el corazón del golfo de Biafra y porque se avistaba como lugar idóneo para iniciar la penetración en el continente "If Fernando Po was occupied 'the whole trade of Northern Africa from the source of the Senegal to Darfur, and from Bornou to Benin' would accrue to Britain” (Lynn, 1990: 196). Esto aseguraría el monopolio del comercio. Esta propuesta fue formalizada por Hay, secretario permanente de la oficina colonial en 1825, y fue posteriormente aprobada en 1827. Al tiempo que se hacían planes para trasladar la Court of Mixed Commission desde Freetown a Fernando Póo, el capitán W. F. W. Owen 
se embarcó para la isla junto a una comitiva de cientos de personas, entre ellos más de 500 esclavos libertos de Sierra Leona (Owen, 1833). Al llegar le compró una milla cuadrada a los jefes bubis, fundó la ciudad de Clarence y estableció allí la base para vigilar el comercio de esclavos en el golfo de Biafra. Muchos recapturados fueron llevados a Clarence en lugar de Sierra Leona. Sin embargo, bien pronto las mismas críticas que se emplearon contra Sierra Leona se prodigaban ahora en Fernando Póo: la alta mortalidad, el excesivo coste y las alegaciones de fraude y escaso control financiero, el comportamiento del coronel E. Nichols hacia los comerciantes y esclavos libertos, favoreciendo unos frente a otros y obligando a trabajar a estos últimos, la dudosa situación legal de los africanos liberados y llevados a Fernando Póo (¿por la fuerza?) cuando debían pasar por la Corte Suprema para el control del comercio de esclavos que seguía en Freetown, el alto consumo de ron, la insalubridad de su aire... La llegada a Fernando Póo y la potencial expansión colonial se basaban en la falsa premisa de que la isla de Fernando Póo permanecía libre de reclamo por otras potencias europeas (Lynn, 1990: 200). España se alertó de esta situación y entró en negociaciones con Gran Bretaña. Tras las fallidas negociaciones para comprar la isla a España, en agosto de 1832 el secretario colonial Goderich dio orden de abandonar la isla. No obstante, el interés por Fernando Póo permanecía, alimentado incluso por Buxton quien detuvo la publicación de su libro The Remedy en 1839 para no perjudicar posibles acuerdos. Él mismo destacaba su ubicación, ser potencialmente más saludable, lo fértil de la tierra y las materias primas que se podían exportar (Buxton 1840: 347-349). A esto ańadía:

"but it would be still more important to the civilization of Africa, forming, as it does, the key to the centre of that vast continent, and in this view, to the philanthropist, its occupation by the British Crown would be invaluable, as the prepossession of the natives on the opposite coast (from which it is distant only a few miles) in favour of the English, over all other nations, is very remarkable" (Buxton 1840: 537)

Estamos pues en una nueva etapa en la política colonial africana británica que va desde 1838 hasta 1842 y que se había iniciado con la creación de la Anti-Slavery Society, la African Civilization Society ${ }^{295}$ y la expedición del Níger

295 Creada para la evangelización de África a través de agentes nativos (Carta desde Kingston, Jamaica 1839 y citada en Buxton 1840: 494). Basándome en la original idea del reverendo James Frederick Schön (1842) y retomada por Bela Vassady (1979) abundaré más adelante sobre el papel de los 'agentes nativos' (native missionaries, native schoolmasters, 
en 1841. El interés ya no estaba en el comercio de esclavos sino en el comercio del aceite de palma además de la posible expansión hacia el delta del Níger y el control de la Costa de Oro.

Paralelamente, las misiones británicas, que habían ampliado su foco de atención desde fuera del país ${ }^{296}$, se especializaron en la década de 1840-1850 en el establecimiento de misiones en distintas zonas geográficas (Bela Vassady, 1979): la Church Missionary Society se ubicó en Sierra Leona donde educó a esclavos liberados que luego envió como 'agentes nativos' para la evangelización (1840); la English Baptist Missionary Society de Jamaica desarrolló sus misiones en Fernando Póo y Camerún (1841); la Basel Presbyterian Missionary Society (Jamaica) asentó sus misiones en Akwopong, Costa de Oro (1843); la Scottish United Presbyterian Church se trasladó desde Jamaica a Old Calabar en Nigeria (1846); y la Anglican West Indian Church (Barbados) orientó su trabajo a Rio Pongo, norte de Freetown, Sierra Leona (1855).

La idea de una misión africana había arraigado en la BMS tras la experiencia en Jamaica, según vimos en el apartado anterior, y con prestancia se organizaron las salidas. El reverendo Clarke y el doctor G.K. Prince fueron destinados a la expedición del Niger pero el gobierno les envió a Fernando Póo porque había elegido ya a dos miembros de la Church Missionary Society y los africanos liberados de Sierra Leona que llevaban consigo para la expedición. En consecuencia, Clarke y Prince fueron a Fernando Póo pero siempre con la mentalidad colonista de expandir el control hacia el interior de África. No fueron pocos los intentos por adentrarse en el continente y Fisher lo refleja muy bien en el diálogo que tiene Clarke con Merrick en la primera escena:

native teachers, native interpreters) como 'brokers’ en la evangelización y civilización de sus coetáneos.

296 Según Thorne, la primera de estas misiones evangélicas tuvo su origen en 1792 entre baptistas de Northamptonshire (Thorne, 1999:24). Aunque rebasa el objetivo de este artículo es importante destacar las potenciales explicaciones sobre el interés y desarrollo de las misiones en el extranjero de Brian Stanley y Susan Thorne. Para Stanley la importancia de los cambios teológicos y la revitalización del protestantismo fueron cruciales y tuvieron un desarrollo autónomo dentro de la historia imperial (Stanley 1992). Según Thorne, el origen del interés se basa "in the multiple transformations and crises that constitued the "age of revolution" in Britain as well as the colonized and soon-to-be colonized world" (Thorne 1999: 26). La explicación, continúa la autora, requiere de un movimiento de ida y vuelta entre el espacio social, geográfico y político entre la metrópoli y la colonia, los que gobiernan y los gobernados. 
"Merrick: We were rather disappointed that you did not actually get to the mainland, as no doubt you were yourselves. You had always talked of the Niger.

Clarke. Yes, it was a disappointment, but our full design proved impracticable, at least for the time. We visited and explored the Niger coastland further along to the Cameroons and we tried to get passage up the Niger, but failed. Any hope of working up to the interior by the river seems impossible at present and the marshy condition of the coast renders it extremely unhealthy. Altogether, the best course seemed to be to make Fernando Poo our base of operations for a commencement."

Fernando Póo permaneció pues como 'cuartel general' y punto de proyección geográfica desde la llegada de la misión baptista jamaicana en 1843 hasta diciembre de 1845 , cuando fueron expulsados por las autoridades españolas y fundaron la misión de Jubilee en Bimbia, Camerún. Desde allí, Joseph Merrick, miembro de la BMS y jamaicano de origen, explotó con éxito la misión ${ }^{297}$. Clarke y Merrick fueron elegidos como pastores en la iglesia de Jubilee y allí trabajaron con los colonos jamaicanos que les acompañaron desde Fernando Póo. En 1846 muchos de ellos, afectados por las insalubres condiciones, decidieron regresar a Jamaica.

\section{A modo de conclusión}

La experiencia de la misión baptista, con la introducción de agentes nativos jamaicanos en Fernando Póo, tenía como objetivo no solo la evangelización de la población nativa sino el poblamiento con colonos jamaicanos (bajo protección británica), el desarrollo del comercio y la avanzadilla hacia el interior del continente africano. Esta idea se basaba en una serie de premisas sobre su mejor adaptación climática, social, cultural y lingüística dado que retornaban 'supuestamente' a la "madre patria" y estaban motivados por la deuda y el agradecimiento hacia los británicos por la emancipación de los esclavos. A ello hemos añadido las características propias de la por entonces sociedad de Clarence, la ideología misionera de combinar el comercio con la civilización, ser independiente económicamente y formar a sus "maestros agentes nativos", así como su estructura

297 Según J. Merrick su principal misión era "to prepare the way of the preaching of the gospel among the Isubu and the Dualas" (Dekar, 2001: 439). Su éxito radicaba en "His apparent acceptance as a white missionary, coupled with his language facility and discreet dealings with chiefs and commoners alike..." (Bela Vassady, 1979: 30) 
organizativa (todos los misioneros se desplazaron con sus familias, lo cual despertó la confianza y alejó el recelo de la población nativa hacia los hombres blancos que llegaban solos). Las características culturales del grupo de los agentes nativos maestros ("coloured") y colonos ("black") jamaicanos que acompañó a Clarke y Prince fueron factores en el fracaso de esta política colonial, según hemos visto. No obstante, frente a los fracasos también podemos enumerar algunos éxitos en tanto que introdujeron plantas desde Jamaica, contribuyeron a abrir el camino del trabajo antropológico y lingüístico ${ }^{298} \mathrm{y}$, sobre todo, abrieron e impulsaron desde Fernando Póo la colonización británica en el interior del continente africano. Los misioneros jamaicanos y británicos baptistas expulsados de Fernando Póo abrieron misiones en Bimbia, Ambas Bay, Camerún (ver mapa anexo S. Nfor Gwei, 1966), donde cultivaron las plantas que habían llevado desde Jamaica a Clarence. Allí continuaron convirtiendo a ex-esclavos al protestantismo pero no ya con la ayuda de los maestros-agentes nativos jamaicanos, puesto que estos habían retornado a África junto con los colonos. La herencia de los baptistas queda patente hoy día en el patrimonio cultural de Bioko, en sus edificaciones (iglesias, colegios) y en el legado identitario que dejaron a una sociedad criolla que formó parte de ese proyecto colonial ${ }^{299}$. Pero más aún, la herencia británica se hizo visible en la expansión hacia el continente africano donde se asentaron las bases para la repartición de parte del pastel en el "Scramble for Africa" entre 1881 y 1914.

298 Además de los trabajos lingüísticos de Merrick sobre el isubu y el duala véase John Clarke 1843, 1846, 1848.

299 Por ejemplo y como también recoge Fisher en su obra de teatro, Barleycorn (krumán llegado en tiempos de Owen) fue enviado a Espańa por los baptistas para que obtuviera el certificado de maestro y poder enseñar en español, aunque a su vuelta se encontró con innumerables problemas para ejercer (Castillo-Rodríguez, 2013).Véase también Baptist Quarterly 15.2 y 15.3. F. W. Butt-Thompson, April 1953. 
La historia se abre y cierra, al igual que este artículo, con este poema de Fisher:

We show you a story

To stir your remembrance,

To bring you a challenge

Behold the beginnings;

In far-off Jamaica

The pioneers storm-driven

Narrate to old comrades

Their Island adventure.

In far-off Jamaica

Where, freed from their slave-chains,

Dark African exiles

Speed thoughts to their homeland.

And long that the Gospel

Their own hearts rejoicing

Shall dawn on their kinsmen

And lighten their darkness.

O greet, then, with honour

These true sons of Carey

By whom God has destined

A heritage of us!. 


\section{BIBLIOGRAFÍA}

BURTON, F. Richard 1872. "A visit to Fernando Po Peak, and a Night in the Open". The Alpine Journal, vol. VI: no XXXVII.

BUTT-THOMPSON, F. W. 1853. “A voyage to Fernando Po”. Baptist Quarterly. 15.2: 82-87. 113-121.

BUXTON, T. S. 1840. The African Slave Trade. England: J. Murray

CASTILLO-RODRIGUEZ, Susana. 2013. Colonizando lenguas: misiones y la politica del español en Guinea Ecuatorial. Dissertation. The Graduate Center, CUNY.

2016: "African Diaspora and the circulation of language: Cuban and Afro-Cuban loanwords in Equatorial Guinea" (en prensa, The International Journal of the Sociology of the Language. Abril 2016: 239)

COOPER, Frederick, and STOLER, Ann Laura, 1997. Tensions of empire: colonial cultures in a bourgeois world. Berkeley, Calif: University of California Press.

CLARKE, John. 1843. The Adeeyah vocabulary for the use of schools in Western Africa. Jamaica Baptist Mission. Printed at the office of the Baptist Herald. Falmouth, Jamaica.

1846. Sentences in the Fernandian tongue. Jubilee Station, Bimbia, Western Africa: ed. at the Dunfermline Press.

1848a. Introduction to the Fernandian tongue. Berwick-onTweed: Printed by D. Cameron. http://catalog.hathitrust.org/api/volumes/ oclc/4716265.html.

1848b. Specimens of dialects: short vocabularies of languages: and notes of countries \& customs in Africa. Berwick-upon-Tweed: Printed by Daniel Cameron.

1869. Memorials of Baptist missionaries in Jamaica, including a sketch of the labours of early religious instructors in Jamaica. London: Yates \& Alexander.

COX, F. A., \& PEGGS, J. 1842. "History of the Baptist Missionary Society". En: History of the Baptist Missionary Society (pp. 1-456).

DEKAR, Paul R. 2001. "Jamaican and British Baptists in West Africa", 1841-1888. Missiology: An International Review, vol. XXIX. N. 4. October.

De KOCK, Leon. 1996. Civilising barbarians: missionary narrative and African textual response in nineteenth-century South Africa. Johannesburg, South Africa: Witwatersrand University Press. 
FISHER, Phil. J. 1926. The Island Heritage. Episodes from the Missionary History of Fernando Poo, West Africa. A Play for Young People. Holborn Publishing House.

JOHNSTON, Anna. 2003. Missionary writing and empire, 1800-1860. Cambridge, England: Cambridge University Press.

GIKANDI, Simon. 1996. Maps of Englishness: writing identity in the culture of colonialism. New York: Columbia University Press.

GUNSON, Niel. 1978. Messengers of grace: evangelical missionaries in the South Seas 1797-1860. Melbourne: Oxford University Press.

GWEI, Solomon Nfor. 1966. History of the British Baptist Mission in Cameroon with Beginnings in Fernando Po, 1841-1886. Dissertation for a Bachelor of Divinity. Baptist Theological Seminary, Rüschlikon-Zürich, Switzerland.

HUTCHINSON, Thomas J. 1858. Impressions of Western Africa. With remarks on the disease of the climate and a report on the peculiarities of trade up the rivers in the Bight of Biafra. London: Longmans and Roberts.

Jamaica and Cameroons Missionary Papers. en mundus.ac.uk

LYNN, Martin. R. S. 1990. Britain's West African policy and the island of Fernando Po, 1821-43. Journal of imperial and Commonwealth history. Vol. 18. Num. 2.: 191-207.

MUDIMBE, V. Y. 1988. The invention of Africa: gnosis, philosophy, and the order of knowledge. Bloomington: Indiana University Press.

NASSAU, Robert Hamill. 1888. A history of the Presbytery of Corisco ... Ogove River, West Coast of Africa, February, 1888. Trenton, N.J.: Press of A. Brandt, Jr. http:// catalog.hathitrust.org/api/volumes/oclc/5316964.html.

OWEN, W. W. (1833). "Narrative of voyages to explore the shores of Africa, Arabia and Madagascar, performed in H.M. Ships Leven and Barracouta under the direction of Captain W. F. W. Owen, R.N”. Two volumes. New York: J\&J Harpert.

RUSSELL, Horace O. 2000. The Missionary Outreach of the West Indian Church. Jamaican Baptist Missions to West Africa in the Nineteenth Century. Peter Lang.

SCHÖN, James Frederick and Mr. Samuel CROWTHER. 1842. Journals. London: Hatchard and Son, Picadilly.

STANLEY, Brian. 1992. The History of the Baptist Missionary Society, 1792-1992. Edinburgh: T \& T Clark.

1990. The Bible and the Flag: Protestant Mission and British Imperialism in the 19th and 20th Centuries. England: Apollos.

STOLER, Ann Laura. 2009. Along the archival grain: epistemic anxieties and colonial common sense. Princeton, NJ: Princeton University Press. 
2013. Imperial Debris: On Ruins and Ruination. Duke University Press. Durham, NC, USA. 04/2013

SPURR, David. 1993. The Rhetoric of Empire: Colonial Discourse in Journalism, Travel Writing, and Imperial Administration (Post-Contemporary Interventions) Paperback - March 18, 1993

SUNDIATA, I. K. 1975. "The Rise and Decline of Kru Power: Fernando Po in the Nineteenth century". Liberian Studies Journal, 25-41.

1996. From Slavery to Neoslavery: The Bight of Biafra and Fernando Po in the Era of Abolition, 1827-1930. Publication Information: Madison: U. of Wisconsin P.

THORNE, Susan. 1999. Congregational missions and the making of an imperial culture in nineteenth-century England. Stanford, Calif: Stanford University Press.

The Adventure of the Road. vol. 1928: 71. En Popular Report of the Primitive Methodist Missionary Society. 5. vols. George Ayre 1928-1932.

UNZUETA Y YUSTE, Abelardo de. 1947. Geografía histórica de la isla de Fernando Póo. Madrid: Instituto de Estudios Africanos.

USERA Y ALARCÓN, Jerónimo M. 1845. Ensayo gramatical del idioma de la raza africana ñano, por otro nombre Cruman: raza noble y una de las más relacionadas en todo el golfo de Guinea y Costa del Africa intertropical del oeste.

VASSADY, Bela. 1979. "Transplanting prejudices: the failure of the Baptist experiment using Jamaican 'native agents' in Fernando Po and Cameroons", 1841-1850. Caribbean Quarterly, (1/2). 15. 
